DOI http://dx.doi.org/10.4314/mlr.v7i1.7

\title{
Locating Big Laws in Small Places: A REVIEW
}

Michael Burgess and G Alan Tarr, eds. (2012), Constitutional Dynamics in Federal Systems: Sub-national Perspectives (Montreal and Kingston: Forum of Federations and McGill, Queen's University Press) $338+$ xii pages.

One of the consequences of having a federal system in place is the potential availability of the opportunity for dual constitutionalism, the co-existence of federal and sub-national constitutions side by side. Federalizing a formerly unitary state (often referred to as federation by devolution, or holding-together federations) leads to the 'creation' or the vacation of some spaces for what I choose to call 'big laws in smaller places'. Thus, constituent units that hardly had powers to generate their own laws come to claim the opportunity to make such laws including basic and fundamental laws such as their own constitutions. This 'space' vacated by the 'national' state of formerly unitary states or left to constituent units by a newly formed (aggregated) federal states has increasingly come to be referred to as 'sub-national constitutional space'. 'The sub-national constitutional space is a realm in which the right to one's own constitution (i.e., the right to constitutional texts, institutions, processes, and constitutional

- Tsegaye R Ararassa is a PhD Candidate at Melbourne University Law School. He can be reached at tsegayer@gmail.com.

${ }^{1}$ Articles and collected essays edited in a book in recent years incude, but not limited to the following: Tarr, 'Explaining Sub-national Constitutional Space' (2011) 115 Penn State Law Rev. 1133; Robert F Williams, 'Teaching and Researching Sub-national Constitutional Law' (2011) 115 Penn State Law Rev. 1109; Jonathan Marshfield, 'Models of Sub-national Constitutionalism' (2011) 115 Penn State Law Review, 1151; Tsegaye Regassa, 'Sub-national Constitutions in Ethiopia: Towards Entrenching Constitutionalism at State level' (2009) 3 Mizan Law Rev. 33; G Alan Tarr, Robert Williams, and Josef Marko, eds, Federalism, Sub-national Constitutions, and Minority Rights Westport, CT: Praeger 2004.; Giacomo Delledonne and Giuseppe Martinico, 'Exploring Subnational Constitutionalism: A Special Issue' (2012) 4(2) Perspectives on Federalism. This is in addition to the Kluwer series monographs on state constitutions. 
identity) is asserted, contested and utilized. As such, it is the realm in which, among other things, sub-national entities' constitutive authority as distinct demos is made visible. The quest for sub-national constitutional space can thus be understood as a quest for 'big laws in smaller places'. While sub-national constitutions $^{2}$ continue to be relatively more invisible in constitutional legal studies, there is a steady increase in recent years in scholarly engagement with the field. This engagement with the sub-national space is the focus of the book under review here, the book edited by the Michael Burgess and G Alan Tarr.

In what qualifies for a boost to an emerging sub-field of comparative federalism, (i.e., comparative sub-national constitutional law), Michael Burgess and G Alan Tarr have offered us their contribution to a better understanding of the dynamics in the relationship between the national and the sub-national levels of government. This edited volume seeks to explore the interplay between the national, subnational, and (in the case of European federations) supranational states and governments. It aims at looking "at the constitutional architecture of [federal] systems from 'below'" (p.3). By noting the attempt to understand federal systems from the perspective of the federal government as top down in approach and incomplete in grasp, the volume emphasizes the importance of the bottom up approach adopted in this volume. In so doing, it seeks to explain, among other things, "how sub-national constitutional autonomy in federal states and federal or quasi-federal political systems" have changed their development (p.20) and "how and why [these systems] have managed to evolve and adapt in both similar and different directions" (p.20). In order to achieve its objective, it raises four major questions to which it responds through analytical chapters that explore twelve case studies. The four questions relate to: (1) what space (i.e., discretion) constituent units have to design their own constitutional institutions

${ }^{2}$ The term 'Sub-national constitution' is used to refer to constitutions and constitutionlike fundamental texts that govern the sub-national space. Thus, they are known as state constitutions in countries such as USA, Australia, Ethiopia, Mexico, etc. They are referred to as Provincial constitutions in countries such as South Africa. The term is also used to refer to Statutes of Autonomy as in Spain or Regional Statutes as in Italy). These latter ones, especially the ones in Spain, are also referred to as 'internal constitutions'. See, for example, Jaoquim Sole Vilanova, "Spain: Developments in regional and Local Government," in Robert J Bennet, ed, Territory and Administration in Europe. New York: St Martin's Press, 1989, pp. 205, 209-13. See also Eduardo Ruiz Viyetez, "Federalism, Sub-national Constitutional Arrangements, and Protection of Minorities in Spain," in G Alan Tarr, Robert Williams, and Josef Marko, eds, Federalism, Sub-national Constitutions, and Minority Rights Westport, CT: Praeger 2004. It is also employed in reference to the 'Basic Laws' of Hong Kong and of Macau (Special Administrative Regions [alias SARs] of the Peoples' Republic of China). See Paulo Cardinal and Yihe Zhang, 'Sub-national Constitutionalism in the SARs of the Peoples' Republic of China: an Exceptional Tailored Suit Model?' (2012) 4 (2) Perspectives on Federalism (Special issue), E 101-147. 
and the extent to which the boundary of that space is policed; (2) what factors influence sub-national constitutions; (3) why sub-national units occupy or fail to occupy spaces available to them; and (4) what consequences emerge from this for horizontal and vertical intergovernmental relations (p.7).

This book is a collection of thirteen essays in total. The essays other than the introduction constitute selected case studies from federal and quasi-federal jurisdictions. The consideration of sub-national constitutions and the dynamics thereof in territorial, multinational, regionalist, and supranational federations is discussed one after the other in four parts. Prefaced by Rupak Chattopadhyay, President of the Forum of Federations, the volume starts with a scene setting introduction by the editors. After this broad introduction that also summarizes and wonderfully connects the thread that runs across all the contributions come the case-specific essays presented under four rubrics.

America's state constitutions and those of the Lander in Germany and Austria (all three of which are described as 'territorially based federations') are treated under the first part. Part II presents the experience in four multinational federations (namely that of Bosnia-Herzegovina, Switzerland, Belgium, and Canada). In part III, we are presented with the experience of three territorially decentralized unitary states namely that of the United Kingdom, Spain, and Italy. In part IV, sub-national constitutionalism and constitutional development is discussed in the context of a supranational federal system, i.e., the European Union. In all the twelve cases presented, the authors tell the story of subnational constitutional space in a diverse array of federal and/or quasi federal settings and suggestively remind us of the dynamics in other federal systems.

In federal systems, the volume seems to suggest, intergovernmental relations is ultimately a function of inter-constitutional dynamics. This in turn suggests to us that we need to trace, track, and have an understanding of sub-national constitutions. This act of tracing and tracking, this act of locating sub-national constitutions, is more than deciding whether there is a single codified constitutional text. Such constitutions come in many forms other than what we conventionally understand by the term 'constitution'.

From the pieces in the volume we learn that our sensibility of tracing subnational constitutions - of locating big laws in smaller spaces - gets refined when we note that they might be embedded (or even hidden) in the federal/ national constitution, or in federal legislation dealing with general or specific matters in the realm of sub-national and local governments, or in acts of state legislatures (state legislatures 'talking back', or 'speaking up' as it were), or in unwritten constitutional conventions and practices (where such practices are sedimented enough to constitute a legal norm), etc.

While the articles from each contributor are free standing, independent, and shedding some light on the dynamics of specific countries taken as case studies, the book has no problem of incoherence or lack of mutual intelligibility among the contributions. This is primarily because of the introductory chapter that not 
only sets the tone for the book (and aptly and summarily captures the contentions of each chapter) but also because of the connecting thread that links each contribution through the questions analysed. And this is irrespective of the difference in the process that led to the federal system (coming together, or holding together), the purpose it was negotiated for (accommodation/recognition of diversity, or administrative efficiency), modes of governing/policing the subnational space (through say, the use of the federal constitution, federal laws and administrative regulations; through enforcing constitutional supremacy; through parliamentary check for consistency; through litigation in constitutional/ supreme courts; through political negotiation and consultation, etc) or the political context, or the legal tradition.

For a volume with a strong accent on its comparative reach, the omission of cases from beyond the transatlantic community ${ }^{3}$ (Asia, Africa, and Latin America) might make it less complete but not less instructive even to those federations that are not covered in the volume. The fact that African federations (such as South Africa and Ethiopia) are only tangentially mentioned but not discussed extensively is unfortunate. Discussion on these federations would have explored the potential of the sub-national constitutional space as a site of negotiating recognition of diversity, plurinationality, and 'internal nationhood'. Sub-national constitutions' potential for institutionalizing recognition is underexplored particularly in postcolonial Africa.

The Ethiopian reader who flips through the pages would be surprised by the points made about Ethiopia in two places (pp.12, and 37) where the editors mention Ethiopia as an example of federal systems in which broader subnational space is conceded by the 'center' as an incentive for the constituent units to join the federation: Another sentence on Ethiopia reads: "the Oromo Liberation Front agreed to cease armed resistance and join the Ethiopian Federation only after the constituent states were guaranteed the right to secede" (p.12).

The editors allude to Yonatan $\mathrm{T}$ Fessha's $\mathrm{PhD}$ Thesis "Institutional Recognition and Accommodation of Ethnic Diversity: Federalism in South Africa and Ethiopia" (2008) as their source. Considering the fact that the Oromo Liberation Front (OLF) joined the transitional government in pre-Charter 1991 with all its arms (i.e., immediately after the collapse of the Derg); and considering that it was back in armed insurgency as the constitution was being drafted and adopted between 1992 and 1994; and considering the continued armed resistance even after the promulgation of the 1995 Constitution, the comment about Ethiopia is rather intriguing.

${ }^{3}$ The twelve cases whose stories are told in the volume are all drawn from Europe and North America. 
Nevertheless, the criticism about its comparative reach being restricted to Euro-America should not discount the critical importance of the volume to any study of 'federalism from below.' Similarly, the comment about the inaccuracies regarding Ethiopia is not so much a criticism as it is a point about the limits of doing comparative constitutional law 'from a distance' relying only on secondary sources. 